\title{
PEMANFAATAN RUMPUT GONG BELITUNG: ERIOFORESTER (ERIOCAULON FOR BREAST CANCER) TERHADAP AKTIVITAS SEL MCF-7
}

\author{
Denox Asih Pratiwi ${ }^{1}$, Rusdiana Kartika Putri ${ }^{2}$, Siti Nurul Komariah ${ }^{3}$, Arde Toga \\ Nugraha ${ }^{4}$ \\ 1,2,3,4Jurusan Farmasi, Fakultas Matematika dan IImu Pengetahuan Alam, Univeristas \\ Islam Indonesia \\ Yogyakarta
}

\begin{abstract}
ABSTRAK
Rumput gong (Eriocaulon cinereum $\mathrm{R}$. Br.) secara turun temurun telah digunakan oleh masyarakat Bangka Belitung sebagai terapi kanker. Studi pendahuluan menunjukkan bahwa ekstrak metanol rumput gong memiliki aktivitas sitotoksik terhadap sel kanker serviks. Salah satu spesies lain Eriocaulon, Eriocaulon australe dilaporkan memiliki efek sitotoksisitas terhadap sel kanker MCF-7, Hela dan A549 [3]. Untuk dapat dikembangkan lebih lanjut, suatu agen sitotoksik harus bersifat selektif terhadap sel kanker. Oleh karena itu, penelitian ini bertujuan untuk menguji aktivitas sitotoksik fraksi dari ekstrak metanol rumput gong terhadap sel MCF-7 dan sel Vero, serta mengidentifikasi golongan senyawa yang terkandung dalam fraksi diklorometan dan air. Proses ekstraksi dilakukan dengan Ultrasound-Assisted Extraction dan fraksinasi dilakukan menggunakan metode partisi cair-cair. Uji aktivitas sitotoksik dilakukan menggunakan metode MTT assay dan nilai absorbansi diukur menggunakan ELISA reader pada panjang gelombang $595 \mathrm{~nm}$. Data dianalisis menggunakan metode PROBIT. Hasil uji sitotoksik menunjukkan nilai Inhibition Concentration $\left(\mathrm{IC}_{50}\right)$ fraksi diklorometan rumput gong terhadap sel MCF-7 adalah 459,86 $\mu \mathrm{g} / \mathrm{ml}$, sedangkan $\mathrm{IC}_{50}$ fraksi air terhadap sel MCF-7 adalah $5473,58 \mu \mathrm{g} / \mathrm{mL}$. Indeks selektivitas (IS) fraksi diklorometan sebesar 0,74 . Hasil analisa selektivitas menunjukkan bahwa fraksi diklorometan kurang selektif pada sel MCF-7. Selanjutnya, nilai $I_{50}$ fraksi diklorometan terhadap sel Vero adalah adalah $341,52 \mu \mathrm{g} / \mathrm{mL}$ dan $\mathrm{IC}_{50}$ fraksi air terhadap sel Vero sebesar $5296,78 \mu \mathrm{g} / \mathrm{mL}$. Identifikasi kandungan senyawa dengan metode kromatografi lapis tipis (KLT) menunjukkan adanya kandungan senyawa golongan alkaloid, steroid, fenolik dan terpenoid pada fraksi diklorometan.
\end{abstract}

Kata kunci: Rumput Gong, Sel MCF-7, Ultrasound-Assisted Extraction, Partisi cair-cair, MTT assay.

\section{PENDAHULUAN}

Angka kejadian kanker payudara di Indonesia diperkirakan sekitar 12/100.000 wanita. Di Indonesia, lebih dari $80 \%$ kasus ditemukan berada pada stadium lanjut. Pada tahun $2018 \mathrm{di}$ Amerika Serikat, kanker payudara didiagnosis pada sekitar 266.120 wanita dan 2.550 pria (Anonim, 2018). Telah banyak upaya yang dilakukan untuk mengobati kanker antara lain pembedahan, kemoterapi, terapi radiasi, termokemoterapi, terapi hormon atau terapi antibodi monoklonal. Pada upaya pengobatan tersebut seringkali muncul efek samping yang merugikan pada jaringan normal (Tyagi et al., 2004).
Dengan masih tingginya angka kejadian kanker payudara di Indonesia maupun di dunia, sangatlah penting dalam penemuan obat baru untuk tercapainya efekifitas terapi serta pentingnya pemanfaatan potensi dari sumber daya alam yang melimpah diantaranya Rumput Gong ( $E$. cinereum R.Br) melatar belakangi peneliti untuk melakukan penelitian ini.

Masyarakat Bangka Belitung secara turun temurun telah menggunakan rumput gong sebagai terapi kanker. Penelitian pendahuluan menunjukkan bahwa ekstrak etanol rumput gong ( $E$. cinereum $\mathrm{R}$. Br) memiliki aktivitas menghambat proliferasi sel 
kanker serviks (sel HeLa) dengan Inhibition Concentration (IC50) 427,79 $\mu \mathrm{g} / \mathrm{Ml}$ (Nugraha et.al., 2017). Spesies Eriocaulon yaitu Eriocaulon australe dilaporkan memiliki efek sitotoksisitas terhadap sel kanker MCF-7, Hela dan A549. Pada salah satu penelitian lain diketahui bahwa ekstrak metanol rumput gong ( $E$. cinereum R.Br) dapat menghambat proliferasi sel kanker serviks dengan nilai $\mathrm{IC}_{50} 475 \mu \mathrm{g} / \mathrm{ml}$, artinya aktivitas antiproliferasinya bersifat lemah terhadap sel kanker serviks. Ekstrak metanol rumput gong (E. cinereum) mengandung senyawa golongan fenolik dan steroid (Lisnasari, 2017). Pada beberapa penelitian melaporkan bahwa senyawa golongan fenolik dan steroid yang diduga memiliki sifat sebagai agen sitotoksik (Chang et al., 2000; Kim et al., 2012). Tujuan dilakukan pengujian dalam bentuk fraksi adalah untuk memisahkan golongan utama kandungan yang satu dari kandungan golongan utama lainnya yang diharapkan memiliki aktivitas sitotoksik yang lebih baik dibandingkan dengan bentuk esktrak.

\section{METODE PENELITIAN}

Alat

Alat yang digunakan pada penelitian ini adalah alat-alat gelas, corong buchner, corong pisah, timbangan analitik (Mettler Toledo), cabinet dryer, rotary evaporator (Heidollph-L4000), desikator, lemari asam, lemari pendingin, LAF (Laminar Air Flow, Labconco), mikropipet (Socorex), vortex, mikroskop inverted (Olympus), hemasitometer (Neubauer), inkubator $\mathrm{CO}_{2}$ (HERAcell), ELISA reader, tangki nitrogen cair, alat sonikator, oven, serta lampu UV254 dan UV366.

\section{Bahan}

Bahan yang digunakan pada penelitian ini adalah rumput gong, $n$ heksan teknis (CV. General Labora), metanol teknis (CV. General Labora), etil asetat teknis (CV. General Labora), diklorometan p.a (Merck), kloroform p.a (Merck), aquadest, sel MCF-7 dan sel Vero dari stok Laboratorium Parasitologi Fakultas Kedokteran Universitas Gajah Mada, 96-well microplates (Iwaki), etanol $70 \%$, media kultur DMEM (Dulbecco's Modified Eagel's Medium)
1640, media kultur M199, FBS (Fetal Bovine Serum), penisilin dan streptomisin, fungizone, PBS (phosphate buffer saline), SDS (sodium dodecyl sulphate) stopper, tripsin $0.025 \%$, DMSO (dimethyl sulfoxide, Merck), reagen MTT 0,5\%, blue tip, yellow tip, silika gel 60 GF254, pereaksi anisaldehid-asam sulfat, pereaksi semprot feri klorida $\left(\mathrm{FeCl}_{3}\right)$, pereaksi aluminium klorida $\left(\mathrm{AlCl}_{3}\right)$, pereaksi semprot dragendorff, dan pereaksi semprot Liebermann-Burchard. Dilakukan proses dengan Ultrasound Assisted Extraction, fraksinasi dilakukan menggunakan metode partisi cair-cair, uji skrining fitokimia dilakukan dengan menggunakan KLT dan uji aktivitas sitotoksik dilakukan menggunakan metode MTT assay.

\section{Cara Penelitian \\ Ekstraksi rumput gong}

Pada penelitian ini rumput gong digunakan dalam bentuk herba sehingga semua bagian tanaman tidak dibuang. Rumput gong yang telah mengering diserbuk dan disimpan pada wadah kaca yang tertutup rapat dan kering dengan tujuan agar jamur atau kontaminan lain tidak tumbuh. Serbuk simplisia rumput gong disari terlebih dahulu dengan menggunakan pelarut $\mathrm{n}$ heksan sebanyak $500 \mathrm{ml}$, kemudian dimasukkan pada alat sonikator. Penyarian kandungan senyawa dilakukan dengan menggunakan Ultrasound-Assisted Extraction selama 30 menit. Ekstrak yang diperoleh dipisahkan dari ampas dengan kertas saring dan corong buchner. Ampas kemudian dilarutkan dengan $500 \mathrm{ml}$ etil asetat untuk diekstraksi kembali dengan tujuan mendapatkan senyawa-senyawa yang bersifat semi polar. Setelah dipisahkan dengan filtratnya, ampas dari hasil ekstraksi dengan etil asetat diberi pelarut metanol sebanyak $500 \mathrm{ml}$ untuk mendapatkan kandungan senyawasenyawa rumput gong yang larut dalam pelarut polar. Setiap proses penyarian dilakukan 3 kali remaserasi. Ekstrak cair yang diperoleh kemudian dipekatkan menggunakan vacuum rotary evaporator untuk mendapatkan ekstrak kental. Setelah pelarut diuapkan hingga kering, ekstrak disimpan di dalam desikator agar tidak lembab dan stabilitas ekstrak tersebut tetap terjaga. 


\section{Fraksinasi Ekstrak Metanol Rumput Gong}

Ekstrak metanol rumput gong dilarutkan dalam aquadest panas, selanjutnya dimasukkan kedalam corong pisah dan dilakukan fraksinasi dengan penambahan pelarut diklorometan sehingga terbentuk dua lapisan yaitu lapisan atas merupakan fraksi air dan lapisan bawah merupakan fraksi diklorometan. Proses fraksinasi dihentikan jika warna fraksi diklorometan berubah menjadi bening dengan tujuan untuk memastikan bahwa sudah tidak terdapat senyawa yang larut didalam diklorometan. Fraksi diklorometan dikeluarkan dari corong pisah dan ditampung. Selanjutnya fraksi air di fraksinasi dengan menggunakan kloroform sampai terbentuk dua lapisan yaitu fraksi kloroform yang berada dilapisan bawah sedangkan fraksi air berada pada lapisan atas. Kedua fraksi tersebut kemudian ditampung. Fraksi diklorometan, kloroform dan air diuapkan pelarutnya dengan menggunakan rotary evaporator untuk memperoleh fraksi kental.

\section{Uji Skrining Fitokimia}

Fraksi dari ekstrak metanol rumput gong dielusi pada plat KLT dengan menggunakan fase gerak berupa campuran $n$-Heksan : Etil Asetat : Metanol (2:5:4) ditambahkan dua tetes asam asetat glasial. Kemudian diidentifikasi secara kualitatif kandungan golongan senyawa kimianya menggunakan pereaksi semprot lieberman-burchard, $\mathrm{FeCl}_{3}$, anisaldehidasam sulfat, $\mathrm{AlCl}_{3}$, dan dragendroff. Dilihat perubahan warna yang terjadi untuk setiap plat.

\section{Kultur Sel MCF-7 dan Sel Vero}

Proses kultur sel dilakukan di LAF (Laminar Air Flow), sel yang inaktif dalam wadah ampul diambil dari tangki nitrogen cair, kemudian dicairkan suspensi sel pada suhu kamar hingga mencair. Ampul dibuka dan suspensi sel dipipet sebanyak $1 \mathrm{ml}$ kemudian dipindahkan ke dalam tabung konikal steril yang berisi media masing-masing sel (M199 untuk sel Vero dan DMEM untuk sel MCF-7). Suspensi sel disentrifugasi 2000 rpm selama 5 menit, bagian supernatan dibuang, endapan putih yang terdapat di dasar konikal adalah koloni sel. Setelah supernatan dibuang, selanjuttnya diganti media dengan media baru kemudian disuspensikan perlahan hingga homogen. Selanjutnya suspensi sel diambil sebanyak $2 \mathrm{ml}$ kemudian ditumbuhkan lagi ke dalam 2 cell culture dish, masing-masing dish ditambahkan dengan $5 \mathrm{ml}$ media kultur dan homogenkan. Cell culture dish tersebut diinkubasikan dalam inkubator $\mathrm{CO}_{2} 5 \%$ dengan suhu $37^{\circ} \mathrm{C}$. Setelah 2-3 hari diamati pertumbuhan sel, jika sel belum konfluen (sel telah memenuhi flask) dapat ditumbuhkan lagi dengan cara mengganti media pertumbuhan yang baru.

\section{Pemanenan Sel}

Setelah jumlah sel cukup, media dibuang dan sel konfluen dicuci dengan PBS secukupnya sebanyak 3 kali sampai bersih dari media, lalu larutan tersebut dibuang. $1 \mathrm{~mL}$ tripsin $0,025 \%$ ditambahkan dan diamkan 5 menit dalam inkubator $\mathrm{CO}_{2} \quad 5 \%$ kemudian diamati di bawah mikroskop inverted dengan perbesaran 100 kali sampai terlihat sel terlepas. Sel diresuspensi dengan penambahan tripsin untuk membantu melepaskan sel dari dinding plate, selanjutnya sel dipindahkan ke tabung konikal. Media kultur $2 \mathrm{~mL}$ dan PBS 1x $10 \mathrm{~mL}$ ditambahkan kedalam tabung konikal, kemudian disentrifugasi dengan kecepatan 1500 rpm selama 15 menit dan supernatan dibuang. Pada sel Vero ditambahkan 1mL media M199 dan media DMEM untuk sel MCF-7, diresuspensi sampai pellet terlepas.

Uji aktivitas sitotoksik

Uji aktivitas sitotoksik dilakukan menggunakan metode MTT assay. Sel dengan kepadatan $10.000-50.000 \mathrm{sel} / \mathrm{ml}$ diambil sebanyak $100 \mu$ l, kemudian sel diletakkan ke dalam mikroplate 96-well dan diinkubasi pada inkubator $\mathrm{CO}_{2}$ selama 24 jam pada suhu $37^{\circ} \mathrm{C}$. Sampel dan media yang akan digunakan sesuai dengan perhitungan pada berbagai konsentrasi ditambahkan ke dalam mikroplate dan dilakukan inkubasi pada inkubator $\mathrm{CO}_{2}$ selama 24 jam. Sebanyak $100 \mu \mathrm{l}$ MTT 0,5\% ditambahkan ke dalam mikroplate, kemudian diinkubasi kembali selama 4 jam pada inkubator $\mathrm{CO}_{2}$. Setelah itu, ditambahkan $100 \mu \mathrm{L}$ SDS stopper (SDS 10\% dalam 0,01 N $\mathrm{HCl})$ dan dilakukan inkubasi pada microplate di suhu ruang selama 24 jam 
dalam kondisi gelap. Setelah proses inkubasi selesai, sampel digoyangkan dengan menggunakan shaker selama 5 menit selanjutnya dianalisis menggunakan ELISA reader dengan panjang gelombang $595 \mathrm{~nm}$.

\section{Analisis Hasil}

Data absorbansi yang diperoleh dihitung untuk melihat jumlah sel hidup dengan menggunakan rumus (Patel et al., 2009):

Persen sel hidup $=\frac{A-C}{B-C} \times 100 \%$

Keterangan: $A=$ Absorbansi sampel

sel

$$
\mathrm{B}=\text { Absorbansi kontrol }
$$

$\mathrm{C}=$ Absorbansi kontrol

media.

Suatu senyawa dikatakan memiliki aktivitas sitotoksik jika pada kadar yang diberikan dapat menghambat pertumbuhan sel kanker yang ditandai dengan jumlah persen sel yang masih hidup. Aktivitas antikanker dinyatakan dalam $\quad \mathrm{C}_{50}$ (konsentrasi yang menyebabkan kematian $50 \%$ populasi sel). Nilai $\mathrm{IC}_{50}$ didapatkan dari korelasi linier antara persen hidup dengan konsentrasi fraksi dan dihitung menggunakan analisis probit.

\section{HASIL DAN PEMBAHASAN Ekstraksi}

Proses ekstraksi dilakukan dengan cara 50 gram simplisia diesktraksi secara bertingkat dengan menggunakan pelarut n-heksan $250 \mathrm{ml}$, etil asetat $250 \mathrm{ml}$ dan metanol $250 \mathrm{ml}$ dengan metode Ultrasound Assisted Extraction. Ekstrak yang didapatkan di kentalkan menggunakan rotary evaporator. Pada penelitian ini hanya menggunakan ekstrak metanol. Berdasarkan hasil esktraksi diperoleh esktrak metanol sebanyak 2,54 gram dengan persen randemen 4,34\%.

\section{Fraksinasi Ekstrak Metanol}

Ekstrak metanol rumput gong dilarutkan dalam aquadest panas kemudian difraksinasi dengan diklorometan terlebih dahulu, kemudian fraksi air di partisi dengan kloroform. Fraksi diklorometan, kloroform dan air dikentalkan dengan menggunakan rotary evaporator. Berdasarkan hasil fraksinasi, fraksi kloroform tidak dapat digunakan untuk uji aktivitas sitotoksik maupun identifiksi kandungan senyawa karena jumlahnya tidak cukup untuk dilakukan pengujian. Selanjutnya, diperoleh fraksi diklorometan sebanyak $739,70 \mathrm{mg}$ sehingga persen randemen yang didapatkan adalah $36,98 \%$, dan fraksi sebanyak 1247,10 mg dengan persen randemen yang dihasilkan sebesar $62,35 \%$.

\section{Uji Skrining Fitokimia}

Uji skrining fitokimia dilakukan dengan menggunakan metode KLT (Kromatografi Lapis Tipis) dan visualisasi menggunakan pereaksi semprot. Untuk uji alkaloid menggunakan pereaksi semprot dragendorff dan menghasilkan perubahan warna menjadi jingga atau oranye gelap (Gibbons, 2005). Uji fenolik menggunakan pereaksi semprot $\mathrm{FeCl}_{3}$ dan menghasilkan perubahan warna menjadi hijau, merah, coklat, ungu, biru, atau hitam yang kuat (Harborne, 1987). Uji terpenoid menggunakan pereaksi semprot anisaldehid asam sulfat dan menghasilkan perubahan warna ungu gelap hingga hitam setelah plat KLT dipanaskan di dalam oven pada suhu $100^{\circ} \mathrm{C}$ selama 5-10 menit (Channel, 1998). Pereaksi semprot liebermannburchard digunakan untuk mengidentifikasi senyawa golongan steroid. Hasil positif akan ditunjukkan oleh pembentukan warna biru tua atau hijau setelah plat KLT dipanaskan dalam oven pada suhu $100^{\circ} \mathrm{C}$ selama kurang lebih 10 menit (Touchstone, 1992). Berdasarkan hasil uji skrining fitokimia menunjukkan bahwa fraksi diklorometan mengandung senyawa golonagan alkaloid, steroid, fenolik dan terpenoid. Selanjutnya fraksi air mengandung senyawa fenolik yang ditandai dengan perubahan warna menjadi hijau, merah, coklat, ungu, biru, atau hitam yang kuat (Harborne, 1987). . Pada penelitian pendahuluan menunjukkan bahwa esktrak metanol dari rumput gong mengandung fenolik dan steroid (Lisnasari, 2017). Mekanisme sitotoksik dari senyawa fenolik hampir sama dengan mekanismenya sebagai antiseptik, dimana senyawa fenolik mampu melisiskan membran sel dan mengendapkan protein yang kemudian menyebakan kematian pada sel (Chang et al., 2000). Senyawa golongan steroid 
mampu menyebabkan kematian pada sel kanker melalui proses regulasi protein $\mathrm{Bcl}-2$, aktivasi p53, modulasi aktivitas caspase-3, dan aktivasi ASK1 yang berperan dalam proses apoptosis (Kim et al., 2012).

\section{Uji aktivitas Sitotoksik terhadap sel} MCF-7

Aktivitas sitotoksik dari fraksi diklorometan dan air dilihat melalui nilai $\mathrm{IC}_{50}$, artinya nilai konsentrasi dari fraksi yang mampu membunuh $50 \%$ sel. Hubungan antara nilai absorbansi dengan jumlah sel yaitu semakin besar nilai absorbansi maka semakin banyak sel hidup. Serapan absorbansi yang terukur yaitu nilai serapan kristal violet formazan yang jumlahnya sama dengan jumlah sel hidup. Kriteria yang digunakan untuk menentukan aktivitas sitotoksik berdasarkan US National Cancer Insitute, adalah: $\mathrm{IC}_{50} \leq 20 \mu \mathrm{g} / \mathrm{ml}$ = sangat sitotoksik, $\mathrm{IC}_{50}$ diantara 21 dan $200 \mu \mathrm{g} / \mathrm{ml}=$ sitotoksik sedang, $\quad \mathrm{IC}_{50}$ diantara 201 dan $500 \mu \mathrm{g} / \mathrm{ml}=$ sitotoksik lemah, $\mathrm{IC}_{50}>500 \mu \mathrm{g} / \mathrm{ml}=$ tidak bersifat sitotoksik (Sajjadi, 2015).

Tabel 1. Hasil Uji Sitotoksik Fraksi Diklorometan dan Air Terhadap Sel MCF-7

$\begin{array}{cccc} & \begin{array}{c}\text { Konsen } \\ \text { trasi } \\ (\mu \mathrm{g} / \mathrm{ml})\end{array} & \text { Rata-rata Absorbansi } & \text { Viabilitas Sel } \\ (\%) & \begin{array}{c}\mathrm{IC}_{50} \\ (\mu \mathrm{g} / \mathrm{ml})\end{array} \\ & \text { Sampel Kontrol Sel Kontrol Media } & & \end{array}$

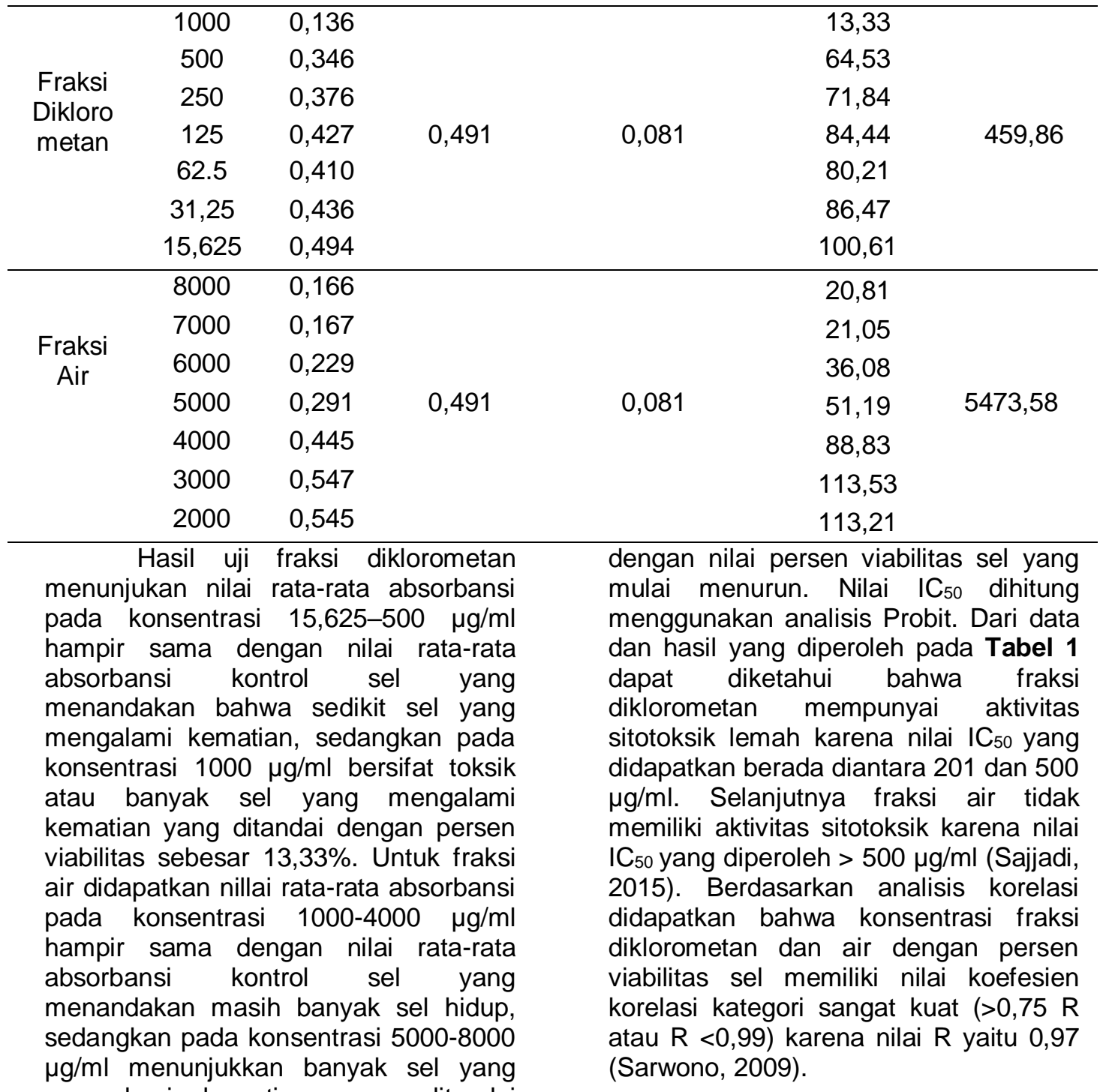




\section{Uji Aktivitas Sitotoksik Terhadap Sel Vero}

Pengujian aktivitas sitotoksik fraksi pada sel vero dilakukan untuk melihat selektivitas. Suatu fraksi dikatakan selektif jika hanya membunuh sel kanker dan tidak menyebabkan kematian pada sel normal (Blagosklonny dan Zbigniew, 2002). Selektivitas ekstrak atau fraksi dalam membunuh sel kanker dapat diketahui dengan menggunakan parameter Selectivity Index (SI). Indeks selektivitas dapat dihitung menggunakan rumus sebagai berikut (Rusdi et al., 2014):

$$
\mathrm{SI}=\frac{I C 50 \text { sel normal }}{I C 50 \text { sel } \text { kanker }}
$$

Semakin tinggi nilai SI maka semakin selektif fraksi dalam menghambat proliferasi sel kanker (Rusdi et al., 2014)..

Fraksi diklorometan dan air dibuat dalam 7 seri konsentrasi. Fraksi diklorometan dibuat dalam seri konsentrasi 450; 400; 350; 300; 250; 200 dan $150 \mu \mathrm{g} / \mathrm{ml}$. Selanjutnya fraksi air dibuat dalam konsentrasi 8000; 7000;
6000; 5000; 4000; 3000 dan $2000 \mu \mathrm{g} / \mathrm{ml}$. Hasil pembacaan absorbansi menggunakan Elisa reader menunjukkan bahwa nilai rata-rata asborbansi fraksi diklorometan pada konsentrasi $150-200 \mu \mathrm{g} / \mathrm{ml}$ tidak jauh berbeda dengan nilai rata-rata absorbansi kontrol sel yang menandakan bahwa sedikit sel yang mengalami kematian, sedangkan pada konsentrasi 350-450 menunjukkan bahwa fraksi diklorometan bersifat toksik yang ditandai dengan persen viabilitas yang semakin menurun viabilitas sebesar 13,33\%. Untuk fraksi air didapatkan nillai rata-rata absorbansi pada konsentrasi 1000-4000 $\mathrm{\mu g} / \mathrm{ml}$ hampir sama dengan nilai rata-rata absorbansi kontrol sel yang menandakan sel masih banyak yang hidup, sedangkan pada konsentrasi 5000-8000 $\mu \mathrm{g} / \mathrm{ml}$ menunjukkan bahwa fraksi air memiliki sifat toksik atau menyebabkan banyak sel yang mengalami kematian, ditandai nilai persen viabilitas sel yang mulai menurun.

Tabel 2. Hasil Uji Sitotoksik Fraksi Diklorometan dan Air Terhadap Sel Vero

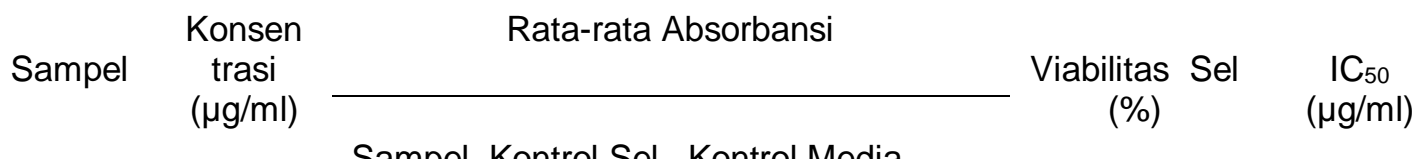

Sampel Kontrol Sel Kontrol Media

\begin{tabular}{|c|c|c|c|c|c|c|}
\hline \multirow{7}{*}{$\begin{array}{l}\text { Fraksi } \\
\text { Diklorom } \\
\text { etan }\end{array}$} & 450 & 0,263 & \multirow{7}{*}{0,680} & \multirow{7}{*}{0,086} & 29,88 & \multirow{7}{*}{341,52} \\
\hline & 400 & 0,334 & & & 41,82 & \\
\hline & 350 & 0,431 & & & 58,02 & \\
\hline & 300 & 0,444 & & & 60,26 & \\
\hline & 250 & 0,470 & & & 64,69 & \\
\hline & 200 & 0,503 & & & 70,12 & \\
\hline & 150 & 0,515 & & & 72,25 & \\
\hline \multirow{7}{*}{$\begin{array}{l}\text { Fraksi } \\
\text { Air }\end{array}$} & 8000 & 0,182 & \multirow{7}{*}{0,680} & \multirow{7}{*}{0,086} & 16,20 & \multirow{7}{*}{5296,78} \\
\hline & 7000 & 0,204 & & & 19,84 & \\
\hline & 6000 & 0,268 & & & 30,72 & \\
\hline & 5000 & 0,346 & & & 43,78 & \\
\hline & 4000 & 0,622 & & & 90,25 & \\
\hline & 3000 & 0,821 & & & 123,66 & \\
\hline & 2000 & 0,799 & & & 120,01 & \\
\hline \multicolumn{4}{|c|}{$\begin{array}{l}\text { Nilai } \mathrm{IC}_{50} \text { fraksi diklorometan dan } \\
\text { air terhadap sel Vero disajikan dalam } \\
\text { Tabel 2. Dari data dan hasil yang } \\
\text { diperoleh nilai IC } \text { C }_{50} \text { fraksi air rumput } \\
\text { gong pada sel Vero sebesar } 5296,78\end{array}$} & \multicolumn{3}{|c|}{ 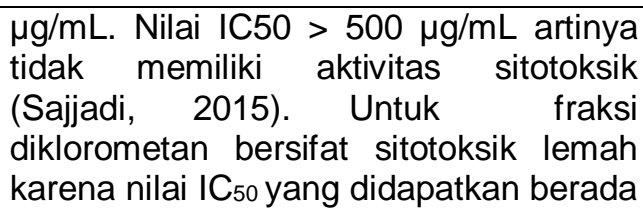 } \\
\hline
\end{tabular}


diantara 201 dan $500 \mu \mathrm{g} / \mathrm{ml}$ yaitu 341,52 $\mu \mathrm{g} / \mathrm{ml}$ (Sajjadi, 2015). Berdasarkan analisis korelasi didapatkan bahwa konsentrasi fraksi diklorometan dan air dengan persen viabilitas sel Vero

Tabel 3. Selectivity Index

\begin{tabular}{cccc}
\hline \multirow{2}{*}{ Fraksi } & \multicolumn{2}{c}{$\mathrm{IC} \mathrm{C}_{50}(\mu \mathrm{g} / \mathrm{ml})$} & \multirow{2}{*}{ Selectivity Index } \\
\cline { 2 - 3 } & Sel MCF-7 & Sel Vero & 0,74 \\
Diklorometan & $459,86 \mu \mathrm{g} / \mathrm{ml}$ & $341,52 \mu \mathrm{g} / \mathrm{ml}$ & ND \\
Air & $5473,58 \mu \mathrm{g} / \mathrm{mL}$ & $5296,78 \mu \mathrm{g} / \mathrm{mL}$ &
\end{tabular}

*ND: No Data

Fraksi dikatakan memiliki selektivitas yang tinggi apabila nilai $\mathrm{SI} \geq$ 3 (Machana, 2011). Nilai SI fraksi diklorometan rumput gong adalah 0,74 , sehingga dapat disimpulkan bahwa fraksi diklorometan dari ekstrak metanol rumput gong dapat membunuh sel kanker maupun sel normal. Untuk fraksi air tidak dilakukan perhitungan nilai selektivitas karena tidak memiliki aktivitas sitotoksik terhadap sel MCF-7 dan sel Vero.

\section{KESIMPULAN}

Berdasarkan hasil uji sitotoksik pada sel MCF-7 menunjukkan bahwa fraksi diklorometan aktivitas sitotoksiknya bersifat lemah terhadap sel MCF-7 dan fraksi air dari ekstrak metanol rumput gong tidak memiliki aktivitas sitotoksik terhadap sel kanker MCF-7. Aktivitas sitotoksik fraksi diklorometan bersifat sitotoksik lemah terhadap sel Vero dan fraksi air tidak memiliki ativitas sitotoksik terhadap sel Vero. Aktivitas sitotoksik fraksi diklorometan dari ekstrak metanol rumput gong kurang selektif pada sel MCF-7. Kandungan senyawa dalam fraksi diklorometan dari ekstrak metanol rumput gong yang teridentifikasi dari profil KLT adalah senyawa golongan alkaloid, steroid, fenolik, dan terpenoid. Pada fraksi air, terdapat senyawa golongan fenolik.

\section{UCAPAN TERIMAKASIH}

Terimakasih kepada Dosen Pembimbing dan Kementerian RISTEKDIKTI yang telah mendanai penelitian ini melalui PKM-PE tahun 2018.

DAFTAR PUSTAKA

Anonim., 2018. Cancer Facts \& Figures. American Cancer Society. Atlanta.1-71. memiliki nilai koefisien korelasi kategori sangat kuat $(>0,75 \mathrm{R}$ atau $\mathrm{R}<0,99)$ karena nilai $R$ yaitu 0,95 (Sarwono, 2009).
Blagosklonny, M.V., Zbigniew, Darzynkiewicz., 2002. Protection of Normal Cells and Unshielding of Cancer Cells. Cell Cycle. 1(6), 375382.

Channel, R.J.P., 1998. Natural Products Isolation. Springer Science \& Business Media. 475.

Chang, Y.C, Tai, K.W., Huang, F.M., Huang, M.F., 2000. Cytotoxic and Nongenotoxic Effects of Phenolic Compounds in Human Pulp Cell Cultures. J Endod. 26(8), 440-3.

Gibbons, S., 2005. An introduction to planar chromatography. Nat Prod Isol.;77-116.

Harborne, J.B. 1987. Metode Fitokimia: Penuntun Cara Modern Menganalisis Tumbuhan, diterjemahkan oleh Kosasih Padmawinata dan Iwang Sudiro, Penerbit ITB, Bandung. pp.9-71.

Kim, D.S., Jeon, B.K., Lee, Y.E., Woo, W.H., Mun, Y.J., 2012. Diosgenin Induces Apoptosis in HepG2 Cells through Generation of Reactive Oxygen Species and Mitochondrial Pathway. Evid Based Complement Alternat Med. 2012:e981675.

Lisnasari, B.R.W., 2017. Aktivitas Sitotoksik Ekstrak Metanol Rumput Gong (Eriocaulon cinereum R. BR.) Pada Sel Kanker Serviks (HeLa) Dan Sel Normal (Sel Vero). Skripsi. Universitas Islam Indonesia. Yogyakarta.

Nugraha, A.T., Ramadhan, V., Pandapotan, H., Romadhonsyah, F., 2017. A Study of Proliferative Activity of Herbs Eriocaulon Cinereum R.Br on Cervical Cancer Cells (HeLa) with MTT Assay Method. International Journal of Pharma Medicine and Biological Sciences. 2(6), 73-76. doi: 10.18178/ijpmbs.6.2.73-76. 
Machana, Sasipawan., Weerapreeyakul, Natthida., Barusrux, Sahapat., Nonpunya, Apiyada., Sripanidkulchai, Bungorn., Thaweesak, Thitimetharoch., 2011. Cytotoxic and apoptotic effects of six herbal plants against the human hepatocarcinoma (HepG2) cell line. Chinese Medicine. 6(39), 2-8.

Patel, S., Gheewala, N., Suthar, A., 2009. In-Vitro cytotoxicity activity of Solanum Nigrum extract against Hela cell line and Vero cell line. International Journal of Pharmacy and Pharmaceutical Sciences. 1(1), 38-46.

Rusdi, M., Alam, G., Manggau, M.A., Wardihan, Lukman., 2014. Selective Cytotoxicity evaluation in Anticancer drug screening of Boehmeria virgata (Forst) Guill leaves to several human cell lines: HeLa, WiDr, T47D and Vero. Dhaka Univ J Pharm Sci. 12(2), 87-90.

Sajjadi, S.E., Mustafa, G., Mehrangiz, H., Leili, M., 2015. Cytotoxic effect of Cousinia verbascifolia Bunge against OVCAR-3 and HT-29 cancer cells. Journal of HerbMed Pharmacology. 4(1), 15-19.

Sarwono, J., 2009. Statistik itu Mudah : Panduan Lengkap untuk Belajar Komputerisasi Statistik Menggunakan SPSS 16. Yogyakarta: Andi Publisher. Hal: 59.

Touchstone JC. 1992. Practice of Thin Layer Chromatography. John Wiley \& Sons; $406 \mathrm{pp}$.

Tyagi, A.K., Agarwal, C.,Chan, D.C.F., Agarwal, R., 2004. Synergistic Anti Cancer Effects of Silibinin with Conventional Cytotoxic Agents Doxorubicin, Cisplatin dan Carboplatin against Human Breast Carcinoma MCF-7 dan MDA-MB468 Cells. Oncology reports. 11(2), 493-499. 